\title{
Syncrisis as literary motif in the story about the grown-up child Jesus in the temple (Luke 2:41-52 and the Thomas tradition)
}

\author{
Author: \\ Andries G. van Aarde $^{1}$ (D \\ Affiliation: \\ ${ }^{1}$ Department of New \\ Testament Studies, Faculty \\ of Theology and Religion, \\ University of Pretoria, \\ South Africa
}

Research Project Registration: Project Leader: A.G. van Aarde Project Number: 2334682

\section{Description:}

This research is part of the research project, 'Biblical Theology and Hermeneutics', directed by Prof. Dr Andries van Aarde, Post Retirement Professor and Senior Research Fellow in the Dean's Office, Faculty of Theology and Religion, University of Pretoria.

Corresponding author: Andries van Aarde, andries.vanaarde@aosis.co.za

Dates:

Received: 06 Sept. 2018 Accepted: 10 Nov. 2018 Published: 18 Feb. 2019

How to cite this article: Van Aarde, A.G., 2019, 'Syncrisis as literary motif in the story about the grown-up child Jesus in the temple (Luke 2:41-52 and the Thomas tradition)', HTS Teologiese Studies/ Theological Studies 75(3), a5258. https://doi.org/ 10.4102/hts.v75i3.5258

\section{Copyright:}

C 2019. The Authors. Licensee: AOSIS. This work is licensed under the Creative Commons Attribution License.

\section{Read online:}

Scan this QR
code with your
smart phone or
mobile device
to read online.

Syncrisis as literary motif in the story about the grown-up child Jesus in the temple (Lk 2:41-52 and the Thomas tradition): The article explores hermeneutical solutions for the negative response from the child Jesus towards his biological parents in the Lukan temple story (Lk 2:41-52). The 'wisdom' of the child who acts in an 'adult-like' way is interpreted as a syncrisis. This literary motif is explained by an analysis of the contrasting positive and negative acts of the child Jesus towards teachers of the Torah in the Infancy Gospel of Thomas.

\section{Introduction - the child Jesus teaches rabbis ${ }^{1}$}

When Jesus was 12 years of age, so the writer of the Gospel of Luke narrates, and Jesus was in the temple with Joseph and Mary, he sat among the rabbis in an adult-like manner ( $\dot{\varepsilon} v \tau \tilde{\omega}$ i $\dot{\varepsilon} \rho \tilde{\varphi}$

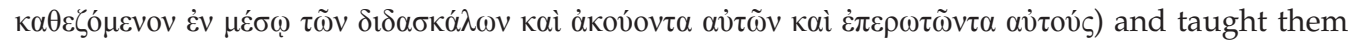
questions and answers about God (Lk 2:41-52). In my contribution to the Festschrift for Jurie le Roux (see Van Aarde 2013b), I pointed out that knowledge about the ancient cultural history helps us to understand Luke's message. Thus, the 1st-century education confirms the view that infants entered their childhood at the age of three and that it lasted until the beginning of puberty.

Wiedemann (1989:51) starts his discussion about the model childhood of leading men in antiquity with the statement that these men were 'not ordinary citizens', but that they were 'abnormal super human beings'. Numerous inscriptions attribute wisdom to children that are out of keeping with their age (see Kleijwegt 1991:126-130, in Chartrand-Burke 2010:265). The ideal that all children should have the characteristics of an adult, was prominent in Mediterranean culture with the result that the qualities of children, even in the non-elitist part of society were treated with contempt. It was for example not uncommon in tomb iconography (Huskinson 1996:80; 1997:237-238, in Chartrand-Burke 2010:263-264) to place the image of a child's portrait on top of the body of an adult. These children, still too young to enter the adult world of their parents, are portrayed as the young adults their parents would want them to be.

By the time that the children reached the age of 12, for most of them schooling in the Roman and Israelite societies was at an end (Chartrand-Burke 2010:334 n. 6; cf. Cribiore 2009:257). ${ }^{2}$

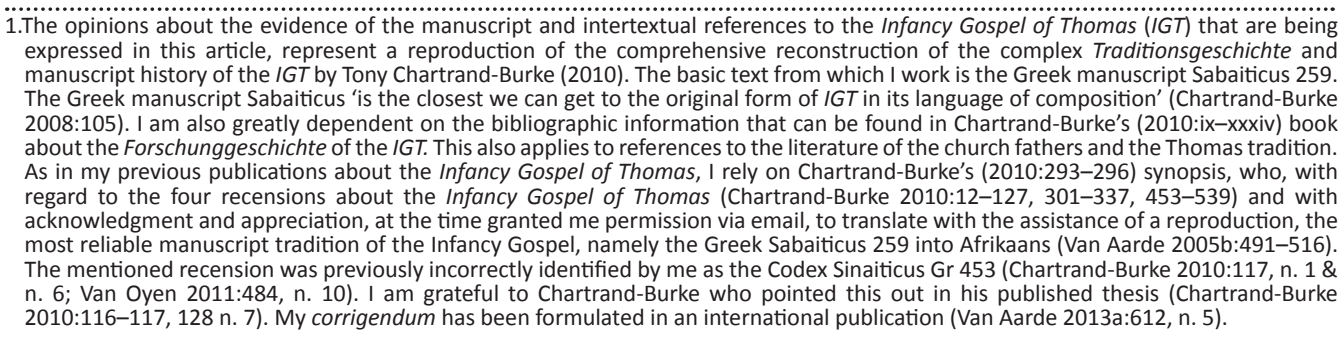

2.Chartrand-Burke $(2010: 239, n$. 2) points out that the Roman boys at the age of 15 or 16 became full citizens in the political meaning of the word. By this time, they had exchanged their 'garment of boys' (the bulla and toga praetexta) for that of a man (the toga virilis). Boys of that age, however still had to learn much about how to be a 'man'. The full responsibility of a grown man, which included financial independence, as well as an important political ranking and to get married, stood over until the youth was closer to 25 years of age (see Kleijwegt 1991:72). About the same applied to young men in formative Judaism. The rabbis determined that a child's legal responsibility began at puberty, but for a man, marriage was not envisaged before the age of 30; even at 20 a young man was still regarded as being naïve, rebellious and not yet as a 'full beard'. If gifted, they could be chosen to continue their education, this time at the feet of teachers and philosophers (see Marrou 1956:160-216; Safrai \& Stern 1976:953, in Chartrand-Burke 2010:239, n. 2).

Note: The collection entitled 'Eben Scheffler Festschrift', sub-edited by Jurie H. le Roux (University of Pretoria) and Christo Lombaard (University of South Africa).

This article is dedicated to Eben Scheffler on the occasion of his acceptance of his retirement as university professor. Since the 1970s, during our earliest student days at the University of Pretoria, we have been friends. As students we studied the ancient languages and $I$ during our earliest student days at the University of Pretoria, we have been friends. As students we studied the ancient languages and
had the privilege to act as one of his external examiners for his doctoral thesis about the Gospel of Luke. We have been colleagues for four decades, Eben as a professor at the University of South Africa and I associated with the University of Pretoria. We both are followers of Jesus with an interest in the scientific investigation of the historical Jesus. We also share an interest in cross-border studies of the Old and New Testaments, as well as the social-psychological exegesis of ancient documents. This article focusses on this scientific interest. 
Ancient writers therefore portrayed the heroic figures in their stories in such a manner, that they possessed the abilities already in their youth, for which they were to be known in later life. The qualities that one would normally expect children to have - playfulness, impulsiveness, disobedience, however not innocent (cf. Bakke 2005:3-9, in Punt 2017:252; Punt 2017:236) - are all absent in such texts and are replaced with qualities that were highly regarded in adults of 1st-century Mediterranean culture. Qualities such as wisdom, maturity, conformity and self-control generally appear in child narrations about revered persons in Graeco-Roman literature (see Chartrand-Burke 2010:247, 250-261). This was also the case with the characterisation of Jesus in the Gospel of Luke. This text was written by a Greek scholar, socialised in a 'jüdischen Milieu' (Wolter 2008:10). In his culture there were reports of youth who possessed exceptional adult wisdom. The 12-yearold Daniel possesses wisdom and spiritual maturity (see De Jonge 1978:323, in Chartrand-Burke 2010:258-259). Josephus (Antiquitates Judaicae 8.2,211) emphasises Solomon's youth at the beginning of his kingship (Feldman 1988:555).

According to Luke, the roots of Jesus' wisdom were not based on the education given by his parents or the instructions by rabbis but was as a result of God's presence in his life. Walter Schmithals' (1980:44) view is that it was Luke's intention with the story of the temple to emphasise the loyalty Jesus' family had towards the conventions, but this view is too vague and general. There is more to this story. Kingsbury (1994:213) is closer to the core of the narration when he points out that the child Jesus, when he was in the temple, knew that he is the Son of God. More specifically, it is more about Jesus' wisdom (Bultmann 1968:300), as well as his role as teacher (Kilgallen 1985:553-559) in the temple as the place of the kebôd Yahwê, the 'mighty presence of God' (Baltzer 1965:266). It is my opinion, seen from his perspective and religious background, that Luke uses this story to show in what way Jesus is the son of God. Joseph and Mary are witness to his exceptional wisdom and the readers of that time understood that Jesus' wisdom did not come from his parents. The presence of Mary and Joseph in the temple, together with the 12-year-old Jesus who taught the rabbis God's wisdom, should rather be understood in terms of syncrisis as literary motif, than that it would be biographical historiography.

According to Klyne Snodgrass (2008:517) in a syncrisis, 'by its very nature [...] positive and negative processes and entities' are being contrasted. Brookins (2011-2012:45), with reference to Hermogenes (Progymnasmata 20 - edited by Rabe [1913] 1969:1-27), points out that a syncrisis was not only a 'comparison of similar or dissimilar things, or of lesser things to greater things or greater things to lesser things' of the Stoic rhetoric, but at grass-roots level it was well known and generally used in the context of, for example, 'good', 'bad', and 'pain' as was used by Luke. Hans Dieter Betz (1979:289) interprets Jesus' Torah wisdom in the Sermon on the Mount and especially the contrast of 'wisdom' - 'foolishness' in terms of a syncrisis. Brunt (1985:495) views the use of syncrisis as a literary motif part of topoi in ancient Greek rhetoric, where everyday matters are in focus, such as friends, sex, money, wine, food and parents. In Luke the biological family of Jesus is such a topos of everyday life. In my view, the temple story in Luke 2:41-52 about Jesus as an adult-like child, who was more obedient to his heavenly father than to his biological parents, ${ }^{3}$ can be interpreted as an example of syncrisis. This perspective is, in my opinion, confirmed by the Thomas tradition as found in the Infancy Gospel of Thomas (IGT).

\section{The Thomas tradition}

The Greek manuscript tradition of the Infancy Gospel of Thomas contains in the three most prominent Greek versions (see synopsis in Chartrand-Burke 2010:465-539) the reference to 'Thomas the Israelite' ${ }^{4}$ (Chartrand-Burke 2010:466). Although the definitions in the titulus of the different versions cannot be considered as being authentic - also not in the Greek version of Sabaiticus 259 (Chartrand-Burke 2010:302,n. 2), the reference to the name 'Thomas' in the opening verse of Sabaiticus 259 should not be ignored (contra Chartrand-Burke 2010:116), because of the occurrence of this specific titulus in the reception history of the IGT, as if the IGT cannot be interpreted without the titulus. The question arises whether there exists a relevant relatedness between the syncrisis motif in Luke's temple story about the child Jesus and the Thomas tradition. More specifically: Is there a relation between Jesus' wisdom versus the 'wisdom' of the teachers of the Torah and Jesus' behaviour in the Infancy Gospel of Thomas as possible part of the Thomas tradition? The only mention of the Infancy Gospel of Thomas in another text of the Thomas tradition appears in the Acts of Thomas 79, without being any the wiser about the person of 'Thomas'. Helmut Koester ([1980] 1982:208) says that just as the Nag Hammadi document, (The Book of Thomas the Contender) (Nag Hammadi Codex II, 7), the Acts of Thomas draws:

[T] he aretalogical tradition of the apostles' miraculous deeds into the process of Gnostic interpretation: individual miracle stories become descriptions of the encounter of the heavenly world and its messenger with the lower world of demons and transitoriness. (Koester ([1980] 1982:208)

The reference to the 'child Jesus' in the Acts of Thomas 79 can be understood as a reference to Jesus, the Christ in the Infancy Gospel of Thomas. In this reference in the Acts of Thomas a Gnostic connotation is granted the miraculous behaviour of the 'adult-like' child Jesus:

Believe in Christ who was born so that those who have been born may live through his life; who also grew up as a child so that complete maturity may arise from his adulthood. He taught his disciples, because he is the teacher of truth and the wisest among the wise (author's translation of original Greek, in ChartrandBurke 2010:30).

Not only by the conspicuousness of the name 'Thomas' in the Infancy Gospel of Thomas, but also by the probable reference to the Infancy Gospel of Thomas in the Acts of Thomas 79, the question arises whether the most important document

3.Wolter (2008:148) describes these first words of Jesus in the Lukan narration as the beginning of the 'inhaltliche Entfremdung und als symbolische Vorwegnahme des späteren Zerbrechens der überkommenen Familienbeziehungen.'

4.I translated the quoted phrases from the Infancy Gospel of Thomas in this study from the original Greek, unless otherwise stated. For the Greek text of Sabaitcus 259 [Gs], see Chartrand-Burke (2010:301-337). 
in the Thomas tradition, namely the Gospel of Thomas (Nag Hammadi Codex II, 2 [see Evans, Webb \& Wiebe 1993:88-144]), does not have tangential points with the Infancy Gospel of Thomas that can help us to precisely state in detail the codex of the last mentioned. The frequently mentioned parallels ${ }^{5}$ include GospThom 4 ('the man of many days will not hesitate to ask a small 7-day-old child about the place of life') with the Infancy Gospel of Thomas (IGT), Greek Sabaiticus 259, 7:3 ('friends, I ponder about my honour and shame, because I am an old man and defeated by a little child'); GospThom 9 (the parable of the sower) with IGT, Greek Sabaiticus 259, 11 ('when Joseph at [another] time sowed seed, the small child Jesus also sowed one measure of seed. And his father harvested $100 \mathrm{big}$ measures. And he gave to the poor and the fatherless children') and GospThom 77 ('cleaved a piece of wood, I am there') with the Infancy Gospel of Thomas (IGT) Greek Sabaiticus 259, 16 ('Again when a certain young man cleaved wood into equal parts, his foot sole was cut open and he died as a result of blood loss. When a commotion ensued, Jesus ran [there] and after he made his way through the crowd, he grabbed the injured foot and it was immediately healed. And he told the young man: Go, chop your wood').

An evaluation of the possibility that the Infancy Gospel of Thomas indeed breathes a 'Gnostic' spirit based on the prominence thereof by the writer(s) of the Acts of Thomas and the above-mentioned reference in the Gospel of Thomas, invites three points for discussion. Firstly, a reflection on the function of the name 'Thomas' in the Infancy Gospel of Thomas. Secondly, the question arises whether the contents of the Infancy Gospel of Thomas indeed contain a Gnostic doctrine of salvation. And thirdly, the consideration of a Syrian or Egyptian context as possible origin of the Infancy Gospel of Thomas, because the Gospel of Thomas possibly originated in these regions or was at least known in these surroundings.

It is widely accepted that the origin of the Thomas literature (Gospel of Thomas, Acts of Thomas and the Book of Thomas the Contender) must be found in Syria (Fallon \& Cameron 1988:4213-4230; Roukema 1998:159; Uro 2003:24). The question is whether the presence of the name of 'Thomas' in the Infancy Gospel of Thomas means that also the Infancy Gospel of Thomas has its origin in Syria? The parallels in content between the Infancy Gospel of Thomas and the other Thomas-related texts, however, are too insignificant to link material from Infancy Gospel of Thomas, Greek Sabaiticus 259 with the Gnostic orientation in the Thomas literature. Since the discovery of the Nag Hammadi library in Upper Egypt in 1945 (see Robinson 1998:77-110) has the Gospel of Thomas reached the foreground as far as the Gnostic literature is concerned (see Patterson 1998:33-75). It is, however, an open question whether the Gospel of Thomas can be characterised as 'Gnostic' (see Riley 1994:229). Besides, the Infancy Gospel of Thomas should not be seen as part of the Thomas literature. The absence of Thomas' name in the earlier versions of the Infancy Gospel of Thomas shows that the authorship of Thomas in the Infancy Gospel of Thomas, the Greek Sabaiticus 259, was late as well as unknown in the Syrian milieu (Chartrand-Burke 2010:206).

5.My translations based on the texts reproduced from Chartrand-Burke.
In my view, the most explicit verdict is that the message of the Infancy Gospel of Thomas centres around Jesus, who, is as a god-child, the Redeemer of the Israelites in the recension Greek Sabaiticus 259, 16:3. Just before this (probably the most reliable) Greek version of the Infancy Gospel of Thomas in Chapter 17 connects to the childhood passage in Luke 2:42-52, the story ends in 16:3 with significant words. The Israelite crowds acknowledge Jesus as god-child with the words, 'he has saved many souls from death and he has the power to save [people] all the days of his life.' Other versions of the manuscript defer the reaction of the crowds to the end of Chapter 18. The reason for this editorial shift is possibly to mitigate the negative impact of Jesus as the worker of miracles of punishment and to change it into a single, positive image. The version in the Greek manuscript in the Greek Sabaiticus 259, does not show this tendency. Here the 'paradox' of blessing and curse is being maintained: the first mentioned as reaction to the understanding of Jesus as god-child, and the latter as reaction to the lack of this insight. At the same time, the characterisation of Jesus as adult-like child, just as in the Gospel of Luke, stands out in relief. The most evident connection between the Gospel of Luke and the Infancy Gospel of Thomas, is the story of Jesus in the temple. ${ }^{6}$ On the grounds of these similarities and the lack of other inter-canonic motifs in the Infancy Gospel of Thomas (Greek Sabaiticus 259) it seems that Luke, and perhaps with it Acts, were the only Christian texts that were known to the author of Greek Sabaiticus 259 and the Infancy Gospel of Thomas (Chartrand-Burke 2008:102, 107; 2010:221). Within the space of only two centuries have the versions of the Infancy Gospel of Thomas in Greek, Syrian, Arabic, Ethiopian, Latin, Georgian and Slavonic spread further throughout the Roman Empire (see graphic representation 'Manuscript Transmission Stemma', in Chartrand-Burke 2010:222). By the end of the 4th century, it was known to Epiphanius ${ }^{7}$ in Cyprus, as well as to the writers of various non-canonical texts in Egypt. ${ }^{8}$

6.T.................................... Sabaiticus 259) and the Gospel of Luke often end their stories with characters that either return to their houses (Infancy Gospel of Thomas 3:3;14:4; perhaps 7:4; LK $1: 23,56 ; 2: 20,39,51 ; 5: 25 ; 7: 10 ; 23: 49 ; 24: 12$ ) or move forward (Lk $4: 14,30 ; 5: 16$ 7:50; 8:39; 9:56; 10:37; 17:14, 19; 24:52) (Chartrand-Burke 2010:204).

7.Epiphanius, Panarion 51.20.2-3 (in Patrologia Graeca [edited by Migne] 41:923D-925A): 'Because John did not say that Christ did not go to a wedding before the temptation, Christ also did not fulfil any divine signs or at all preached them before the temptation - except perhaps those that were told about him which he did as a child. Because he was also supposed to have performed miracles as a child, to deprive the other heresies of a pardon, that argued that "the Christ", with child, to deprive the other heresies of a pardon, that argued that "the Christ", with
reference to the dove, came to him [after his baptism] in the river Jordan' (author's reference to the dove, came to him [after his baptism] in
translation from the Greek in Chartrand-Burke 2010:7).

8.Epistula Apostolorum 4 (2nd century) (Clavis Apocryphorum Novi Testamenti [CANT] edited by Geerard [1992] 22; 2d, c [my translation of Chartrand-Burke's $\{2010: 29\}$ English translation of the Ethiopian version]): 'It is what our Lord Jesus Christ, that was received by Joseph and Mary, his mother, did when he had to learn the alphabet. And he who taught him, says to him while he taught him; "say Alpha". And when he answered, "First tell me what Beta is". And this did indeed happen in this manner' (author's own translation). Gospel of Bartholomew 2:11 (4th century) (CANT 63) (text in Vassiliev1893, Anecdota graeco byzantina, 1, 1, 10-22): 'Mary told them (the Apostles): according to your parable the Lord created the sparrows and sent them to the four corners of the earth' (my translation of the Greek text in Chartrand-Burke 2010:31). History of Joseph the woodcutter (CANT 60) (author's Chartrand-Burke 2010.31). History of Joseph the woodcutter (CANT 60) (author's own translation based on the English translation of the Arab version by Elliott [1993:114-117] in Chartrand Burke 2010:32): 'Oh Lord, do not for this reason wish me harm, because I am ignorant about the mystery of your birth. I also remember my Lord, the day that the boy died from a snakebite. And his family wanted to surrender you to Herod, because they claimed that you killed him, but you raised him from the dead and returned him to them. Then I went to you, took your hand and said, "My son, look after yourself". But you answered me, "Are you not my father in the flesh? I shall teach you as to who I am"' (author's own translation). 


\section{The Infancy Gospel of Thomas and Jesus as 'adult-like' child}

The Infancy Gospel of Thomas starts with Jesus who as a 5 -year-old used his divine power to purify dirty rainwater in Nazareth. He creates birds of clay and brings them to life with the instruction, 'away, fly as the living'. When another boy, the son of the high priest Annas, stirs the water that Jesus had purified, Jesus cursed the boy and his arm immediately shrivelled. Anyone else who would dare to anger Jesus would encounter a similar fate. A boy, who accidentally knocked against Jesus' arm, drops dead and when the inhabitants of the village complained to his father Joseph, they become blind. Even Joseph is gently urged: 'It is enough for you to search for me and not find me!' When the teacher Zacchaeus tried to teach Jesus a degree of respect, he is put to shame by Jesus' superior knowledge. He tries to regain his honour by praising Jesus in public for something 'great'. This pleases Jesus and he changes his attitude and behaviour. Jesus begins to use his powers to the advantage of his neighbours and heals a young man who has a fatal wound. As 6-year-old he uses only his kethōneth/chitōn [a piece of cloth worn next to the skin] to fetch water for his mother. As 8-year-old he sows a measure of grain and reaps a miraculous crop. When his father, the carpenter, makes a bed for a rich man, he lengthens a piece of woods so that it is of the same length as the other piece. Joseph, who pays attention to the child's wisdom, takes him to a second teacher. However, Jesus refuses to recite the alphabet. When the teacher hits him over the head, Jesus curses him and he breaks down. A third teacher tries hard to teach the boy, but Jesus elucidates the Torah to all present. Like Zacchaeus, this teacher recognises that Jesus needs no education and Jesus continues with his heroic deeds. He saves his brother Jacob from a snakebite and awakes both a baby and the builder of a house from the dead. The Infancy Gospel of Thomas ends with a story form the Gospel of Luke, where Jesus as a 12 -year-old visits the temple in Jerusalem. Where Luke writes that Jesus listens to the rabbis and asks questions, the Infancy Gospel of Thomas tells that he also explains the Torah and the parables.

The Infancy Gospel of Thomas is, according to Sarah Currie (1993:207), a Gnostic document that advocates Docetism (Chartrand-Burke 2010:250). According to her, in the story of the temple in the Gospel of Luke, the emphasis is on Jesus' 'intellect'. The Infancy Gospel of Thomas differs and serves as evidence of Christ's precocity, 'but nothing more'. However, Ronald Hock (1995) and Chartrand-Burke (2010), are rightly of the opinion that there are no tangential points between the Infancy Gospel of Thomas and the Nag Hammadian Gospel of Thomas and Gnosticism, and rather prefer comparisons with ancient biographical literature.

In my view, it is especially the reference to the mother of Jesus in the Greek Sabaiticus 259 of the Infancy Gospel of Thomas, that emphasises a non-Gnostic tendency. This Greek version of the manuscript of the Infancy Gospel of Thomas emphasises the biological aspect of the mother's womb and the physical feeding of a baby by its mother. Thus, for example, the remark, 'what from a mother's lap gave him birth or what kind of mother fed [him]? I do not know!' (in the Infancy Gospel of Thomas, Greek Sabaiticus 259, 7:2), acknowledges the role of the mother of Jesus' biological mother. This version in the Greek Sabaiticus 259 stayed more faithful to the Gospel of Luke than the other Greek manuscripts of the Infancy Gospel of Thomas (see ChartrandBurke 2010:183). The recognition of the positive role of the mother of Jesus appears explicitly in Luke. Luke 2:51 reports that Jesus was obedient to his mother and that 'his mother kept all his words in her heart'. At the beginning of this portrayal of the child Jesus in the temple, Luke (2:22) quotes Exodus 13:2 to emphasise the acceptability (that is to say, the 'holiness') of the physical procreation and birth of a child - in this case Jesus - before God: '[E]very man who opens the womb, will be called holy before God' (author's translation of Ex 13:12).

Our knowledge of the ancient, classical literature brought to light that one of the intentions of the Greek, Roman and Israelitie children's stories about heroic figures, was to demonstrate a consistency of character (Miller 2003:133) for which the hero became known in adulthood. In some cases, these stories raise the status of a child to such a degree, that it includes a nearness of the divine sphere, so that we can even speak about a god-child (Miller 2003:134-135). It also seems to be the case with the portrayal of Jesus in the Greek Sabaiticus 259 of the Infancy Gospel of Thomas. The narrator of this biographical-discursively gospel aligns Luke's narrative to Hellenistic-Semitic and Graeco-Roman biographical parallels where the child as protagonist exceeds the wisdom of his teachers - just as the child Jesus does in both the Infancy Gospel of Thomas and the Gospel of Luke.

Hock (1995:96) explains the heroic deeds of the child Jesus in the Infancy Gospel of Thomas as if he were an adult, by claiming that the readers of ancient biographies would not expect to observe the personality development of a character, since 'character was supposed to be embedded at birth'. The author of the Infancy Gospel of Thomas, according to ChartrandBurke (2010), believes that:

$[H]$ is young Jesus is consistent with the Jesus and apostles of the New Testament. He [Jesus] is magnanimous and wise, not because he is not really human - neither Gnostic saviour, nor child - but because these things make him, in the eyes of the author and audience, human. (p. 289; cf. also Chartrand-Burke 2010:288; 2012:388-400)

Chartrand-Burke (2008) is further of the opinion that the Infancy Gospel of Thomas must be seen as an intentional complement to the Gospel of Luke:

[T] he author of IGT apparently was not completely satisfied with Luke's gospel. He may have approved of Luke's rhetorical style and Christology, but his desire to supplement the gospel with additional childhood stories suggests that he felt Luke was in some way deficient. IGT's changes to the Temple story further indicate that the author wished to supply something lacking in the tale. The problem is simple: compared to other venerable 
figures in ancient biographies, Luke's Jesus [is] not powerful enough, and not wise enough [...]. The author of IGT, it seems, felt Luke did not go far enough in foreshadowing Jesus' adult career; thus, additional stories were required to elevate Jesus above of the eminent figures. (pp. 113, 116)

From this perspective, Jesus as child, works miracles in the Infancy Gospel of Thomas because his adult image does so (Chartrand-Burke 2010:289). He curses certain people in his company because the narrator highly regards the adult Jesus on the same level as a prophetic Eliah and the heroes of the Graeco-Roman literature. The narrator paints Jesus in an 'unorthodox manner', but not as a result of a Docetist Christology or Gnostic contempt of the world. According to Cousland (2017), the Infancy Gospel of Thomas, emphasises three character traits of Jesus that, according to him, do not interfere with the wholeness of the description of his personality in the Infancy Gospel of Thomas, namely: 'holy terror', 'child' and 'miracle-working saviour'.

My interpretation, however, has another nuance. Although the Infancy Gospel of Thomas directly links up with Luke's temple story and Jesus' adult-like behaviour towards the rabbis in the presence of Mary and Joseph, I understand the characterisation of Jesus in the Infancy Gospel of Thomas as being more 'independent' of Luke. I therefore agree with Michel Wolter (2008:146), that the Infancy Gospel of Thomas has dependently 'eigene Akzente' about the child Jesus, compared to Luke's temple story about the child Jesus.

In the Greek Sabaiticus 259 of the Infancy Gospel of Thomas, Jesus has been well socialised in the context of his biological family, the Israeli neighbours and Israelites in general, who find themselves amidst non-Israelites in the diaspora (cf. Van Aarde 2013a:619-620). It remains a question, however, why the author of the Infancy Gospel of Thomas describes the miracles of Jesus, as if he were - as in Luke's temple story - an adult, in a positive as well as a negative light. The answer to this question, in my opinion, sheds light on the specific narrator's perspective with regard to the 'wisdom' of the child Jesus in the Infancy Gospel of Thomas. This answer at the same time offers an explanation of the 'otherness' of the Jesus in the Infancy Gospel of Thomas compared to the Gospel of Luke.

\section{Jesus - the god-man child}

The portrayal of Jesus in the Greek Sabaiticus 259 of the Infancy Gospel of Thomas fits the pattern of the god-child myth - a type of story that shows the hero's connection with the divine that hints at his future raised position. The Jesus in the Infancy Gospel of Thomas (in the Greek Sabaiticus 259) awakens a boy from the dead (Infancy Gospel of Thomas 9), curses his adversaries (Infancy Gospel of Thomas 3:2-3; 4:2; $5: 1 ; 13: 2)$, and performs a variety of miraculous acts that include the bringing back to life of birds (Infancy Gospel of Thomas 2:4), the purification of water (Infancy Gospel of Thomas 2:1), the extension of a wooden beam (Infancy Gospel of Thomas 12:2) and the carrying of water in a leaky piece of clothing (Infancy Gospel of Thomas 10:2). Other narratives hint at specific episodes during Jesus' adult years that had meaning for the Ebionite early Christian faith communities in their multifarious and multilocated settings: the sending forth of the 12 Apostles (IGT 2:4) and the conflict with the Pharisees about the view on the Sabbath (IGT 2-3). Even his encounter with the son of Annas refers to the later conflict between Jesus and the high priest. In the Infancy Gospel of Thomas, however, it is the high priest Annas (represented by his son) that suffers and not Jesus.

Some of the narrations in the Infancy Gospel of Thomas have strong similarities with other children's stories. The tutor episode, that also includes the periscope 'Jesus in the Temple' (Infancy Gospel of Thomas 17), shows that Jesus surpasses his tutors, just as Philo's Moses (in De Vita Mosis 1.5-1.24, in Cohn [1896] 1962). Heracles, just like Jesus, even beats his teacher (and kills him - Apollodorus 2.4.9, Bibliotheca Mythographi Graeci I). The legends of Cyrus (in ChartrandBurke 2010:252), that have been rewritten by Herodotus (Historiae 1.14-15, in Legrand [1932] 1970), tell of an unexpected eloquence of a 10-year-old who was chosen as king. All these children, whether they are gods, poets, emperors, statesmen or saints, are respected for their gift to be able to learn. Adult wisdom is the stamp of the idealised representations of these figures as children. People in the 1st century would of necessity make the connection between the Jesus of the Infancy Gospel of Thomas and the other figures.

There is no aspect in the version of the Greek Sabaiticus 259 of the Infancy Gospel of Thomas that would upset readers of the stories of ancient times. John Chrysostom ${ }^{9}$ (c. 386-398 AC) of Antioch and Epiphanius ${ }^{10}$ of Salamis (376 AC) furnished negative comment on the stories in the Infancy Gospel of Thomas (see Chartrand-Burke 2010:44), apparently not because the scope gave offence, but because they contradicted John's (Jn 4:46, 54) claim that Jesus performed no miracles before his first sign in Cana (Jn 2: 1-12) (Chartrand-Burke 2010:6). In the 4th century, within the context of the 'orthodox' early Christendom, it was ideologically important that there should be, according to the standard of the regula fidei, harmony between the accepted gospels. That Jesus could be an accessory worker of miracles of punishment, did ideologically, however, according to the expectations of society in antiquity, not create any problems. On the contrary, the depiction of Jesus in the Infancy Gospel of Thomas, is in line with the commonly accepted pre-modern mythological paradigm during the first 18 centuries of the survival of this infancy gospel. Of the earliest commentators of the Infancy Gospel of Thomas

9.John Chrysostomos, Homilae in Joannem (17): 'Therefore, in short, it is clear to us that the miracles that some attribute to Christ's childhood, are false and merely concoctions of those who bring it to our attention' (in Patrologia Graeca, [editor Migne], 59:410, in Chartrand-Burke 2010:6)

10.Epiphanius, Panarion 51.20.2-3 (in Patrologia Graeca editor Migne] 41:923D-925A, in Chartrand-Burke 2010): 'Because John had not said that Christ had gone to a wedding before the temptation, neither had Christ performed any divine sign before the temptation, nor did he preach at all-except perhaps that what $h$ ulfilled as a child in play. Because herformed miracles as a child, to deprive the other heresies of an excuse that argue that "the Christ", with reference to the dove, came to him [after his baptism] in the rive Jordan' (p. 7). 
(see Chartrand-Burke 2010:3-44) only a single in a 6th - 7th century list of apocrypha - that has been inserted in the De receptione haereticorum of Timothy of Constantinople, ${ }^{11}$ refers to the Infancy Gospel of Thomas as 'Docetist' and 'adoptionist' and is therefore in conflict with the 'orthodox' early Christendom.

It rather seems that the Greek Sabaiticus 259 of the Infancy Gospel of Thomas was written with the awareness that it should be understood against the background of other literature, especially the Lukan Acts. The inclusion of Luke's temple story anticipates a continuation of Jesus' adult career and could also assume Luke's version of the conception of Jesus (by analogy of that of the emperor Augustus).

\section{Honour-shame conflict as syncrisis}

Eric Stewart (2015:6 of 9) understands the 'normalcy' of the violent actions of the adult-like child Jesus in the Infancy Gospel of Thomas as 'reflective of hegemonic masculinity in the Roman world.' In my opinion, the negative stories in the Infancy Gospel of Thomas represent the pattern of a typical Mediterranean conflict of disgraced honour ('challengeriposte') between Jesus and the teachers (see Malina 1993a:36-37; 1993b:8-10). If they confirm his superior divine wisdom (as in Luke's temple story), Jesus acts as friend, brother and son to the advantage of his family and neighbours (as extended family). If the teachers do not recognise his wisdom, Jesus acts according to miracles of punishment. ${ }^{12}$ This editorial tendency is, in my view (see Van Aarde 2013a:611-626), Ebionitic in character (contra Frédéric Amsler in Cousland 2017:100-102).

Yet Jesus is no ordinary child. He fits the archetype of the god-child. Carl Jung (in Segal 1998) describes this motif as follows:

One of the essential features of the child motif is its futurity. The child is potential future [...]. It is therefore not surprising that so many of the mythological saviours are child gods. This agrees exactly with our experience of the psychology of the individual, which shows that the 'child' paves the way for a future change of personality. In the individuation process, it anticipates the figure that comes from the synthesis of conscious and unconscious elements in the personality. (p. 27)

Jesus' 'status' of god-child is being described in different ways in the Infancy Gospel of Thomas. He possesses maturity and wisdom that do not fit his youthful age. Even at the age of 15, Jesus reacts with cryptic proverbs and enigmatic

11.Timothy of Constantinople, De Recesptione haereticorum (in Patrologia Graeca [edited by Migne] 86:22C, in Chartrand-Burke 2010:10-11): 'The so-called history of the childhood of the Lord that those recorded that saw his human incarnation as an illusion and not a reality, want to proclaim.'

12. This does not mean that there exist no other nuances in the Infancy Gospel of Thomas. It is, for example possible to interpret the curse invoked against Annas son as a vaticina ex eventu from a post-70 AD perspective, - 'your fruit (shall be) without root and your stream shall dry up as a branch that has been broken by a strong wind' (Infancy Gospel of Thomas 3:2). The implicit Torah criticism with regard to the hallowing of the Sabbath day (Infancy Gospel of Thomas 6:4) can also be understood as a polemic reference to the wisdom of the Israelite temple elite. This criticism of the temple ideology does, however, not weaken the Ebionitic tendency in the Greek Sabaiticus 259 of the Infancy Gospel of Thomas. teachings to those around him. ${ }^{13}$ His divine wisdom manifests in especially his encounters with teachers and older persons (Infancy Gospel of Thomas 6:8-10, 8:1, 14:2-4, 17:2-4). These 'manifestations' arouse the feeling with bystanders that Jesus is different in a way 'either a god, or an angel' (Infancy Gospel of Thomas 7:4). Concerning the 'divinity' of the child Jesus, the portrayal of Jesus in the Infancy Gospel of Thomas indicates a resemblance with the young Moses, Apollonius and Heracles. They all evidently possess superhuman wisdom, but the source of their wisdom is never explicitly made public. The portrayal of the child Jesus in the Infancy Gospel of Thomas, therefore, indicates the characteristics of an acceptable ideal of antiquity.

The story of 'Jesus and the tutor' forms the centre of the structure of the Greek manuscript of the Infancy Gospel of Thomas in Codex Sabaiticus 259. The first reference comprises about a third of the document. It forms, with the additional tutor episodes, a threefold narrative with a central theme, namely that it is the child Jesus and not the adult tutors that teach. This power and wisdom bring Jesus, like Moses, Apollonius and Heracles, into close proximity of the divine. Like these heroic figures, Jesus is a god-child. All the other narratives in the Greek Sabaiticus 259 of the Infancy Gospel of Thomas reflect this theme and display Jesus' power and authority as god-child. From the moment he enters the classroom, this boy is already filled with knowledge. He has never been taught but can nevertheless teach. Jesus' wisdom has divine origin.

However, what is important to recognise in the message of the Greek Sabaiticus 259 of the Infancy Gospel of Thomas, is that the portrayal of Jesus - although consistent with the idealised portrayal of children in ancient biographies - was not idealised in this manner because his parents did not want him to be as such. The social expectations of parents for their children in ancient society generally differed from IGT's portrayal of the expectations of Jesus' parents for Jesus. The Jesus of the Infancy Gospel of Thomas himself is the adult-like, god-child, irrespective of what his family or friends, or tutors expected him to be.

What we have in the Infancy Gospel of Thomas, is not a human child that is idealised as divine but a god-child that is presented as a human being. However, to read Docetist or adoptianist motives into the Infancy Gospel of Thomas, is to not distinguish the version of the Greek Sabaiticus 259 of the Infancy Gospel of Thomas from the other Greek recensions of this infancy gospel. Such an error in interpretation results from the lack of identifying a syncrisis as literary motif in both the temple story in Luke 2:41-52, as well as in the Infancy Gospel of Thomas.

13.The first indication of this is found in Jesus' answer to his father's chastisement in the Infancy Gospel of Thomas 5: 'And Jesus said to him: It is enough for you to search for me and not to find me, but do not be grieved. While you obviously have search for me and not to find me, but do not be grieved. While you obviously have an ignorance, you do not together with the light, see that I come from you. Look you do not know how to sadden me. Because I am yours and I surrender to you (v. 3). Shortly thereafter the discourse of revelation of Chapter 6 follows, that brought everybody that listened to silence (Infancy Gospel of Thomas 6): 'And the Jews called out loud and said to him: "Oh, what a new and unbelievable miracle! The little child is probably [only] five years old and, oh, what words does he not speak. These words we never knew, nobody ever spoke them, except this little child - another teacher of the Law, another Pharisee!"' (v. 5). 
In the Greek Sabaiticus 259 of the Infancy Gospel of Thomas it is not about whether Jesus the god-child was actually human and is therefore now introduced as being human. This picture of Jesus is the result of 'Gnosticising' and all signs thereof in the sources have been wiped out in the Greek Sabaiticus 259 by the narrator.

From the perspective of a social-scientific explanation of this Greek manuscript it could be said that the narrator in this biographical-discursive childhood gospel draws and shows the young Jesus as an adult and a sage, not because he is or is not really human, but because his adult wisdom (while he is a child) makes him - the god-child - human in the eyes of the disciples of the early Ebionite Christianity. By the time Jesus is given this recognition, namely that Jesus is a godchild - as the narratives about the tutors in the Greek Sabaiticus 269 of the Infancy Gospel of Thomas testify, the divine boy acts as brother and friend with compassion towards family and friends.

\section{Social-psychological relevance}

The studies about the god-child myth can therefore help to existentially, in a hermeneutical manner, unlock the literary motif syncrisis in the Infancy Gospel of Thomas. According to Jung, the god-child myth serves to encourage the ordinary adult to recognise his or her unconscious and to integrate it with the ego-unconscious (Segal 1998:27). Therefore, contra Freud, myths aid psychological growth, rather than to slow it down. The writer, philosopher and anthropologist Roland Barthes (1957:142-143) describes the function of myth to 'empty reality' and to fill the empty history with nature. This means that everyday experiences are being projected onto the world of the imagination; in other words, 'reality is being emptied'. The world of the imagination consists of representations that correspond to everyday experiences, in other words, the 'empty history' is filled with nature. Life crises are often made bearable by living through alternating states of consciousness (James [1902] 1985:388), or as another researcher puts it:

$[M] y t h$ transforms history into nature by stealing language from one context then restoring it in another so that it appears like something 'wrestled from the gods' when in fact it is simply recycled language. (Salyer 1995:267)

For Jung ([1956] 1967) the human mind is inclined to express symbolically what cannot be understood intellectually. $\mathrm{He}$ argues that the potential to formulate archetypal meaning is already present in people before language is mastered. It appears that the archetypical content is like a blueprint for the organisation of subjects that repeatedly occur in human experiences, like the mythical child as symbol for the lifelong psychological process of growing up (Jung [1949] 1984:244-255; cf. Segal 1998:28). In different cultures and at different times, according to Jung, the archetypal content will be expressed symbolically in different ways, but it will nevertheless reflect the underlying basic human experience. Segal (1998:28) formulates Jung's concept of the psychological function of the mythical child as follows: 'Child myths depict children as both youngsters and future adults. The child is truly the father to the man.' The god-child Jesus in the Infancy Gospel of Thomas was in the context of early Christianity apparently such a symbol for the Ebionite communities.

Today we still live according to our own god-child Jesus myth - as, for example, our Christmas tradition(s) show(s). Mircea Eliade's wording is 'almost identical psychologically'. For Eliade (in Meadow 1992:188-189), myths give sacral or religious meaning to physical objects and human actions. According to Eliade, they are thus exemplary models, human acts through which one relives the myths that give meaning to religious life. Reliving the myth abolishes time and puts one in touch with the real. It is archetypal that to be child-like is not considered to be of value. This behaviour does not hold good only for antiquity (cf. Dasen 2011:312; Punt 2017:248 n. 16), but also for the present day. Maturity is preferred more than 'immaturity'. Similar to the child who does not want to be a child, an adult also often wants to be somebody other than himself or herself. In general, we cannot find authenticity in what we are. By implication, we struggle to notice the godliness in non-adulthood. It is difficult to identify God in 'being child'. Conventionally wisdom is only found in adults! In the ancient Mediterranean literature, the god-child myth was an expression of this human behaviour. The conception of the god-child Jesus in the Greek recension of the Infancy Gospel of Thomas in Sabaiticus 259 tells a similar story but emphasises the presence of the divine in 'being child' and not in being adult. This infancy gospel will help us as adults to see that we regard our children too early as adults, because we manipulate our children to fulfil our own ambitions. In this way we deprive ourselves and our children of the existence to be human. However, recognising the divine in the child, and humaneness becomes possible. That is the existential message of the Greek Sabaiticus 259 of the Infancy Gospel of Thomas about Jesus' kind actions and healings. The alternative is an inauthentic existence that is described in the syncrisis in this version of the Infancy Gospel of Thomas in narratives about 'punishment miracles' and killings. The god-child myth wants to restore the sacred in the 'being child' and wants to take 'adulthood' as human wholeness from the adult world and make it part of the life of a child.

The syncrisis in the temple story in Luke 2:41-52 tells that the mother of Jesus, Mary, perceived this wisdom despite the negative rejection by the 'adult-like' child of his biological parents. The positive contrast in the syncrisis is the obedience to the heavenly father. By means of syncrisis as literary motif, the mother's heart that nurtures the wisdom, becomes a topos (Lk 2:51). In the Acts of the Apostles (4:23-31), this divine wisdom of the 'god-child Jesus' ( by reason of his crucifixion (Ac 4:27) was held up as an example by Luke for the disciples Peter and John, as well as for other believers in the midst of trauma (Ac 4:31).

Eric Stewart (2015) is of the opinion that precisely the absence of the mention of Jesus' crucifixion in the Infancy Gospel of Thomas has made it possible, that an 'adult-like child' with 
the help of the syncrisis elements (my interpretation and not that of Stewart) of contrasting negative and positive actions, could confirm his 'hegemonic masculinity' according to 1stcentury Mediterranean conventions:

[I]n the Jesus traditions found within the New Testament, one of the most difficult aspects of presenting Jesus as a hegemonic male, rather than a subordinated or marginalised male, is the fact of his crucifixion. What makes the Infancy Gospel of Thomas interesting in this regard is that there is no need to treat this episode of Jesus of Jesus' life in a story about his childhood. Though Jesus is a 'boy' throughout the text of the Infancy Gospel of Thomas, the fact that his death is not narrated there leaves the author free to present Jesus as a hegemonic man. (Stewart 2015:5 of 9)

This study demonstrates the presence of the literary motif syncrisis in both Luke's temple story and the Infancy Gospel of Thomas, specifically the child's disobedience to his biological parents and the religious leaders. The study also argues that this similarity does not mean that the Infancy Gospel of Thomas represents a continuity of content and Christological substance. Whatever the topos in the Mediterranean context of the Infancy Gospel of Thomas may be - the convention regarding the 'hegemonic masculinity' or the conventions of the early Christian Ebionism - it is in my opinion clear that, in spite of the similarity with regard to the use of the literary technique of syncrisis, the Jesus tradition in Luke's Gospel, as distinguished from the Thomas tradition (Infancy Gospel of Thomas), has, as Wolter (2008:146) shows and is confirmed in this study - an 'eigenen Akzent'.

\section{Acknowledgements}

\section{Competing interests}

The author declares that he has no financial or personal relationships which may have inappropriately influenced him in writing this article.

\section{References}

Bakke, O.M., 2005, When children became people: The birth of childhood in early Christianity, transl. B. McNeil, Fortress, Minneapolis, MN

Baltzer, K., 1965, 'The meaning of the temple in the Lukan writings', Harvard Theological Review 58(3), 263-377. https://doi.org/10.1017/S0017816000031394 Barthes, R., 1957, Mythologies, transl. A. Lavers, Hill and Wang, New York.

Betz, H.-D., 1979, 'The Sermon on the Mount: Its literary genre and function' The Journal of Religion 59(3), 285-297. https://doi.org/10.1086/486705

Brookins, T., 2011-2012, 'Dispute with Stoicism in the parable of the Rich Man and Lazarus', Journal of Greco-Roman Christianity and Judaism 8, 34-50.

Brunt, J.C., 1985, 'More on the topos as a New Testament form', Journal of Biblical Literature 104(3), 495-500. https://doi.org/10.2307/3260926

Bultmann, R., 1968, History of the Synoptic Tradition, transl. J. Marsh, Basil Blackwell, Oxford.

Chartrand-Burke, T., 2008, 'Completing the gospel: The Infancy Gospel of Thomas as a supplement to the Gospel of Luke', in L. DiTommaso \& L. Turcescu (eds.), The reception and interpretation of the Bible in Late Antiquity: Proceedings of the Montréal Colloquium in Honour of Charles Kannengiesser, 11-13 October 2006, pp. 101-120, Brill, Leiden.

Chartrand-Burke, T., 2010, De Infantia lesv Evangelivm Thomae, Brepols, Turnhout (Corpus Christianorum, Series Aphocryphorum, 17).

Chartrand-Burke, T., 2012, 'Depictions of children in the Apocryphal Infancy Gospels' Studies in Religion / Sciences Religieuses 41(3), 388-400. https://doi.org/10.1177/ 0008429812441338

Cousland, J.R.C., 2017, Holy terror: Jesus in the Infancy Gospel of Thomas, Bloomsbury Publishing, London.
Cribiore, R., 2009, 'The education of orphans: A reassessment of the evidence of Libanius', in S.R. Hübner \& D.M. Ratzan (eds.), Growing up fatherless in antiquity, pp. 257-272, Cambridge University Press, Cambridge.

Currie, S., 1993, 'Childhood and Christianity from Paul to the Council of Chalcedon', $\mathrm{PhD}$ dissertation, University of Cambridge, http://ethos.bl.uk/OrderDetails.do?uin= uk.bl.ethos.357738

Dasen, V., 2011, 'Childbirth and infancy in Greek and Roman antiquity', in B. Rawson (ed.), A companion to families in the Greek and Roman worlds, pp. 291-314, Wiley-Blackwell, Oxford. (Blackwell Companions to the Ancient World).

De Jonge, J., 1978, 'Sonship, wisdom, infancy: Luke 2:41-51a', New Testament Studies 24, 317-354. https://doi.org/10.1017/S0028688500004124

Elliott, J.K., 1993, The apocryphal New Testament, Clarendon Press, Oxford.

Evans, G.A., Webb, R.L. \& Wiebe, R.A. (eds.), 1993, Nag Hammadi texts and the Bible: A synopsis and index, E. J. Brill, Leiden.

Fallon, F.T. \& Cameron, R., 1988, 'The Gospel of Thomas: A Forschungsbericht and an analysis', in W. Haase \& H. Temporini (eds.), Aufstieg und Niedergang der Römischen Welt, Bd. II.25.6, S. 4195-4251, De Gruyter, Berlin.

Feldman, L.H., 1988, Josephus's Interpretation of the Bible, University of California Press, Berkeley, CA.

Geerard, M. (ed.), 1992, Clavis Apocryphorum Novi Testamenti, Brepolis, Turnhout.

Hermogenes [2-3 CE], s.v. 'Progymnasmata', in H. Rabe (ed.) [1913] 1969, Hermogenis opera, pp. 1-27, Teubner, Leipzig.

Herodotos [5 BCE], s.v. 'Historiae', in Ph.-E. Legrand (ed.), [1932] 1970, Hérodote: Histoires, vol. 1, Le Belle Lettres, Paris.

Hock, R.F., 1995, 'The Infancy Gospel of Thomas', in R.F. Hock, The Infancy Gospels of James and Thomas: With introduction, notes, and original text featuring the new Scholars Version translation, pp. 84-158, Polebridge Press, Santa Rosa, CA. (The Scholars Bible).

Huskinson, J., 1996, Roman children's sarcophagi: Their decoration and its social Significance, Clarendon Press, Oxford.

Huskinson, J., 1997, 'Iconography: Another perspective', in B. Rawson \& P. Weaver (eds.), The Roman family in Italy: Status, sentiment, space, pp. 233-238, Clarendon Press, Oxford.

James, W., [1902] 1985, The varieties of religious experience, Penguin Books, New York.

Jung, C.G., [1949] 1984, 'The psychology of the child archetype', in A. Dundes (ed.), Sacred narrative: Readings in the theory of myth, pp. 244-255, University of California Press, Berkeley, CA.

Jung, C.G., [1956] 1967, Symbols of transformation: Collected works, vol. 5, 2nd edn., Princeton University Press, Princeton, NJ.

Kilgallen, J.J., 1985, 'Luke 2, 41-50: Foreshadowing of Jesus, teacher', Biblica 66(4), 553-559.

Kingsbury, J.D., 1994, 'The plot of Luke's story of Jesus', Union Seminary Quarterly Review 39, 213-223.

Kleijwegt, M., 1991, Ancient youth: The ambiguity of youth and the absence of adolescence in Greco-Roman society, J.C. Gieben, Amsterdam.

Koester, H., [1980] 1982, Introduction to the New Testament: History and literature of early Christianity, vol. 2, transl. H. Koester, De Gruyter, Koester.

Legrand, Ph.E., (ed.), [1932] 1970, Hérodote: Histoires, vol. 1, Le Belle Lettres, Paris.

Malina, B.J. 1993a, The New Testament world: Insights from cultural anthropology, rev. edn., John Knox Press, Louisville, KY.

Malina, B.J., 1993b, Windows on the world of Jesus: Time travel to ancient Judea, John Knox Press, Louisville, KY.

Marrou, H.I., 1956, A history of education in antiquity, transl. G. Lamb, Sheed \& Ward, New York.

Meadow, M.J., 1992, 'Archetypes and patriarchy: Eliade and Jung', Journal of Religion and Health 31(3), 187-195. https://doi.org/10.1007/BF00986271

Migne, J.-P. (ed), [1856] 1989, Dictionnaire des Apocryphes, 2 vols. 1856, reprinted, Brepols, Turnhout.

Miller, R.J., 2003, 'Hellenistic infancy narratives', in R.J. Miller (ed.), Born divine: The births of Jesus \& other sons of God, pp. 133-153, Polebridge Press, Santa Rosa, CA

Patterson, S.J., 1998, 'Understanding the Gospel of Thomas today', in S.J. Patterson, J.M. Robinson \& H.-G. Bethge (eds.), The Fifth Gospel: The Gospel of Thomas comes of age, pp. 33-75, Trinity Press International, Harrisburg, PA.

Philo Judaeus [1 BCE-1 CE], 'De vita Mosis', in L. Cohn (ed.), [1896] 1962 Philonis Alexandrinus opera quae supersunt, vol. 4. pp. 119-268, De Gruyter, Berlin.

Punt, J., 2017, 'Not child's play: Paul and children', Neotestamentica 51(2), 235-259. https://doi.org/10.1353/neo.2017.0013

Riley, G.J., 1994, 'The Gospel of Thomas in recent scholarship', Currents in Research: Biblical Studies 2, 227-252.

Robinson, J.M., 1998, 'Nag Hammadi: The first fifty years', in S.J. Patterson, J.M. Robinson \& H.-G. Bethge (eds.), The Fifth Gospel: The Gospel of Thomas comes of age, pp. 77-110, Trinity Press International, Harrisburg, PA.

Roukema, R., 1998, Gnosis \& geloof in het vroegste Christendom: Een einleiding tot de gnostiek, Zoetermeer, Meinema. 
Safrai, S. \& Stern, M., 1976, The Jewish people in the first century, vol. 2, Van Gorcum Amsterdam.

Salyer, G., 1995, 'Myth, magic and dread: Reading culture religiously', Literature \& Theology 9(3), 261-277. https://doi.org/10.1093/litthe/9.3.261

Schmithals, W., 1980, Das Evangelium nach Lukas, Theologischer Verlag, Zürich, (Zürcher Bibelkommentare).

Segal, R.A., 1998, Jung on mythology: Key readings selected and introduced, Routledge, London.

Snodgrass, K.R., 2008, Stories with intent: A comprehensive guide to the parables of Jesus, William B. Eerdmans, Grand Rapids, MI. Stewart, E., 2015, 'Sending a boy to do a man's job: Hegemonic masculinity and
the "boy" Jesus in the Infancy Gospel of Thomas', HTS Teologiese Studies/ Theological Studies 71(1), Art. \#2817, 9 pages. https://doi.org/10.4102/hts. v71i1.2817

Uro, R., 2003, Seeking the historical context of the Gospel of Thomas, Clark, London.

Van Aarde, A.G., 2001, Fatherless in Galilee: Jesus as child of God, Trinity Press International, Harrisburg, PA.

Van Aarde, A.G., [2003] 2016, 'Die heroïese mite van die kind-god Jesus in die Kindheidsevangelie van Tomas', Acta Patristica et Byzantina 14, 266-302. https:// doi.org/10.1080/10226486.2003.11745729

Van Aarde, A.G., 2005a, 'Die Griekse Sabaiticus 259 [corrigendum] van die Kindheidsevangelie van Tomas vertaal in Afrikaans', HTS Theological Studies 61 491-516. https://doi.org/10.4102/hts.v61i1/2.452
Van Aarde, A.G., 2005b, 'Die Kindheidsevangelie van Tomas as 'n heroïese mite van die god-kind Jesus in die konteks van die Ebionitiese vroeë Christendom', D Littproefskrif, Department Ancient Languages, Faculty of Humanities, University of Pretoria, viewed from https://repository.up.ac.za/bitstream/handle/2263/27948/ Complete.pdf?sequence $=10$

Van Aarde, A.G., 2005c, 'The Infancy Gospel of Thomas: Allegory or myth - Gnostic or Ebionite', Verbum et Ecclesia 26, 826-850. https://doi.org/10.4102/ve.v26i3.253

Van Aarde, A.G., 2013a, 'The Ebionite perspective in the Infancy Gospel of Thomas', in J. Schröter (ed.), The Apocryphal Gospels within the context of early Christian theology, pp. 611-626, Peeters, Leuven, (Bibliotheca Ephemeridum Theologicarum Lovaniensium, 260).

Van Aarde, A.G., 2013b, 'Fatherless in Galilee: 'n Outobiografiese refleksie', Verbum et Ecclesia 34(2), Art. \#856, 8 pages. https://doi.org/10.4102/ve.v34i2.856

Van Oyen, G., 2011, 'Rereading the rewriting of the biblical traditions in The Infancy Gospel of Thomas (Paidika)', in C. Clivaz, et al. (eds.), with the assistance of B. Bertho, Infancy Gospels: Stories and identities, pp. 482-505, Mohr Siebeck, Tübingen. (Wissenschaftliche Untersuchungen zum Neuen Testament 2, Reihe 281).

Vassiliev, A., 1893, Anecdota graeco-byzantina, vol. 1, Universtitatis Caesareae, Moscow.

Wiedemann, T., 1989, Adults and children in the Roman Empire, Yale University Press, New Haven, CT.

Wolter, M., 2008, Das Lukas-evangelium, Mohr Siebeck, Tübingen, (Handbuch zum Neuen Testament, 5). 